\title{
Construction delays: a case study in the Brazilian Amazon
}

\author{
Atraso de obras: um estudo de caso na Amazônia \\ brasileira
}

\begin{tabular}{|c|c|}
\hline & $\begin{array}{l}\text { Luiz Mauricio Furtado Maués } \\
\text { Wylliam Bessa Santana } \\
\text { Paulo Cerqueira dos Santos } \\
\text { Renato Martins das Neves } \\
\text { André Augusto Azevedo Montenegro Duarte } \\
\text { Abstract } \\
\text { he construction industry is one of the industrial sectors with the lowest } \\
\text { rates of fulfilment of contract deadlines, especially in developing } \\
\text { countries. This fact has been the focus of considerable discussions } \\
\text { seeking to identify the causes of the delays. The main purpose of this } \\
\text { paper is to use factor analysis to identify the factors that are correlated with delay, } \\
\text { contemplating exclusively residential real estate projects and using a city in the } \\
\text { Brazilian Amazon as a case study. Based on the database from the government } \\
\text { agency that authorises constructions in the city of Belém (City Planning } \\
\text { Department - Secretaria Municipal de Urbanismo, SEURB) and data from } \\
\text { construction companies, the study investigated } 274 \text { construction projects from the } \\
\text { past } 11 \text { years. Factor analysis and work with the variables that can be identified } \\
\text { and measured in the initial phase of the project, i.e., during the feasibility study, } \\
\text { demonstrate that the physical characteristics of the apartments and the construction } \\
\text { project are the primary causes for variations in construction delays; these causes } \\
\text { have not yet been reported in the literature. We hope that the results of this study } \\
\text { will contribute to more consistent forecasting of construction time, minimising the } \\
\text { risk of delays. }\end{array}$ \\
\hline $\begin{array}{r}\text { Luiz Mauricio Furtado Maués } \\
\text { Universidade Federal do Pará } \\
\text { Belém - PA - Brasil }\end{array}$ & $\begin{array}{l}\text { Keywords: Risk. Construction delays. Factor analysis. } \\
\text { Resumo }\end{array}$ \\
\hline $\begin{array}{r}\text { Wylliam Bessa Santana } \\
\text { Universidade Federal do Pará } \\
\text { Belém - PA - Brasil }\end{array}$ & $\begin{array}{l}\text { A construção civil é considerada como uma das indústrias com menor } \\
\text { desempenho em relação ao cumprimento de prazo contratual, especialmente em } \\
\text { países em desenvolvimento, fato este que gera uma ampla discussão que busca } \\
\text { identificar os elementos causadores do atraso. O principal objetivo deste artigo é }\end{array}$ \\
\hline $\begin{array}{r}\text { Paulo Cerqueira dos Santos } \\
\text { Universidade Federal do Pará } \\
\text { Belém - PA - Brasil }\end{array}$ & $\begin{array}{l}\text { utilizar a análise fatorial para identificar fatores que estão correlacionados com o } \\
\text { atraso, limitando-se a presente pesquisa aos empreendimentos imobiliários } \\
\text { residenciais, tendo como estudo de caso uma cidade na Amazônia brasileira. } \\
\text { Através do banco de dados do óró̃o público aue autoriza as obras em Belém }\end{array}$ \\
\hline $\begin{array}{r}\text { Renato Martins das Neves } \\
\text { Universidade Federal do Pará } \\
\text { Belém - PA - Brasil }\end{array}$ & $\begin{array}{l}\text { (SEURB) e os das construtoras, obtiveram-se } 274 \text { empreendimentos em } 11 \text { anos. } \\
\text { Utilizando-se a análise fatorial e trabalhando com as variáveis que possam ser } \\
\text { identificadas e mensuradas ainda na fase inicial do empreendimento, ou seja, no }\end{array}$ \\
\hline $\begin{array}{r}\text { André Augusto Azevedo } \\
\text { Montenegro Duarte } \\
\text { Universidade Federal do Pará } \\
\text { Belém - PA - Brasil }\end{array}$ & $\begin{array}{l}\text { estudo de viabilidade, constatou-se que as características físicas dos apartamentos } \\
\text { e das obras estão entre os principais agentes responsáveis pela variabilidade nos } \\
\text { atrasos dos empreendimentos, o que, pela pesquisa realizada, ainda não foram } \\
\text { apontadas na literatura. Com os resultados encontrados neste trabalho espera-se } \\
\text { contribuir para que se possa definir de forma mais consistente o prazo de } \\
\text { execução, mitigando o risco do atraso. }\end{array}$ \\
\hline $\begin{array}{r}\text { Recebido } \\
\text { Aceito }\end{array}$ & isco. Atraso de obra. Análise fatorial. \\
\hline
\end{tabular}

MAUÉS, L. M. F.; SANTANA, W. B.; SANTOS, P. C. dos; NEVES, R. M. das; DUARTE, A. A. A. M. Construction delays: a 


\section{Introduction}

In 2012, the construction industry in Brazil contributed with $5.6 \%$ of the country's total gross domestic product (GDP) and $21.4 \%$ of the national industrial sector's revenue (INSTITUTO..., 2015). Despite its current importance, the construction industry has not been able to fulfil all its potential for growth in Brazil. The country still has a significant housing shortage: 5,792,508 units in 2012 , with $9.1 \%$ of the population not having adequate housing (FUNDAÇÃO..., 2014).

This gap demonstrates the importance of developing consistent housing policies that can meet the demand without failing to meet customers' cost, time and quality requirements. Due to the evident need for housing in Brazil, construction time is a crucial factor. Hence, companies can maximize the desired results for their projects if they work towards meeting these requirements. Companies should be able to identify the factors that can affect their ability to meet the project's objectives before construction begins (GÜNDÜZ; NIELSEN; ÖZDEMIR, 2013).

With the aim of shedding light on this issue, this study conducted a quantitative investigation of the construction delays that occur in the real estate sector of the city of Belém, Pará. Belém is the second largest city in the Amazon region by land area, with its highest population density, at 1,315.26 $\mathrm{inh} / \mathrm{km}^{2}$, and a total population of $1,439,561$ (INSTITUTO..., 2015).

In the context of residential and commercial building construction, according to the Brazilian Institute of Geography and Statistics (INSTITUTO..., 2012), since 2004, changes in legislation regarding real estate credit have increased legal security for real estate financing through measures such as chattel mortgages.

In this new scenario, according to $\mathrm{BM} \& \mathrm{~F}$ Bovespa's website (2015), property developers raised approximately four billion dollars between 2005 and 2007, when their stocks were launched at an initial public offering (IPO). However, those companies were not used to such a large volume of capital. The new financial situation and the country's economic growth demanded geographic expansion and different construction methods (SOUZA, 2011).

Therefore, companies in the construction and real estate sector reached their limits in terms of production capacity. Moreover, contracted construction projects, several of which had short execution times, became impossible to achieve in the contractual construction times predetermined with the buyers, which led to losses for the all the parties involved. This phenomenon was observed by Felippi and Melhado (2015), who showed that, between 2005 and 2010, construction delays increased by approximately $65 \%$ in the state of São Paulo.

\section{Literature review}

\section{Construction delays}

Project management is the art of directing and coordinating human resources and materials throughout the lifecycle of a project, using management techniques, skills, and knowledge to reach pre-determined goals of scope, cost, quality, time, and satisfaction of the people involved in the project as well as performing risk analysis to assist in decision making (CHAPMAN, 2001; PROJECT..., 2013; WIDEMAN, 1989).

In the search to find more appropriate project management methods, several authors have expressed concerns about companies not being able to meet construction deadlines. Construction delays appear to be a frequent problem worldwide, particularly in developing countries, such as Brazil (ALSEHAIMI et al., 2013; COUTINHO et al., 2012; FILIPPI; MELHADO, 2015; GONZÁLEZ et al., 2014).

We have reviewed papers published in national and international journals during the past twenty-five years in order to identify the causes of construction delays. The Science Direct and Capes periodical databases were used as references in this review. The articles, listed chronologically in Table 1 to help readers to understand the progress of studies on this topic, address the issue of construction delays focusing particularly on variables that can be analysed in the initial phase of the project's feasibility study, which are the object of this article.

At such an early stage in a construction project, the causes traditionally related to construction delays, such as delayed delivery of materials, poor planning and control, rework due to errors during construction, inefficiency of the supplies sector and low labour productivity cannot be defined even in approximate terms. 
Table 1 - Articles on construction delays reviewed in this study

\begin{tabular}{|l|c|c|}
\hline \multicolumn{1}{|c|}{ Authors } & $\begin{array}{c}\text { Year of } \\
\text { publication }\end{array}$ & Country \\
\hline Chan and Kumaraswamy & 1997 & China \\
\hline Mezher and Tawil & 1998 & Lebanon \\
\hline Al-Momani & 2000 & Jordan \\
\hline Assaf and Al-Hejji & 2006 & Saudi Arabian \\
\hline Alaghbari et al. & 2007 & Malaysia \\
\hline Sweis et al. & 2008 & Jordan \\
\hline Dai, Goodrum and Maloney & 2009 & U.S. \\
\hline Fugar and Agyakwah-Baah & 2010 & Ghana \\
\hline Wambeke, Hsiang and Liu & 2011 & U.S. \\
\hline Coutinho et al. & 2012 & Brazil \\
\hline Doloi et al. & 2012 & India \\
\hline Günduz, Nielsen and Özdemir & 2013 & Turkey \\
\hline Akogbe, Feng and Zhou & 2013 & Benin \\
\hline Marzouk and El-Rasas & 2014 & Egypt \\
\hline Othuman Mydin et al. & $2014 \mathrm{a}$ & Malaysia \\
\hline Filippi and Melhado & 2015 & Brazil \\
\hline
\end{tabular}

The issue examined in this study is common in developing countries. However, most of the research has been conducted in developed countries, where the problem is not as relevant or as frequent.

Delays originate from the planning and project definition phases, compressing the construction execution schedule, particularly when the project has a previously set completion date (LEE; DIEKMANN, 2011; YANG; WEI, 2010). In this scenario, managers are obliged to recover this time, increasing uncertainty, risks, and the impact of negative events occurring while completing the project.

The risk management process in a construction project comprises of the following steps: identification, classification, a risk analysis that incorporates the uncertainty factor (qualitatively and quantitatively), and devising appropriate strategies to address the risks (CHAPMAN, 2001; UHER; TOAKLEY, 1999; ZAVADSKAS; TURSKIS; TAMOSAITIENE, 2010; ZOU; ZHANG; WANG, 2007).

The literature review in this investigation found studies concerned with the identification, classification and the most frequent causes of construction delays, e.g., Assaf and Al-Hejji (2006) in Saudi Arabia, Alaghbari et al. (2007) in Lebanon, Fugar and Agyakwah-Baah (2010) in Ghana, Doloi et al. (2012), who identified causes for delays in India, Gündüz, Nielsen and Özdemir (2012) and Kazaz, Ulubeyli and Tuncbilekli (2012) in Turkey, Marzouk and El-Rasas (2014) in Egypt. Alsehaimi et al. (2013) conducted a survey and a critical analysis of the research on this subject, pinpointing the existence of delays in construction projects in 12 developing countries.

According to the survey performed in their research, the primary causes of construction delays worldwide are the following: poor planning and control, inadequate local management, low labour productivity, materials that are outside the specifications or late, financial difficulties, design changes, climate, problems with subcontractors and poor communication between managers and workers.

In addition to the identification of construction delays, some studies have also investigated the consequences of those delays, such as increased construction prices due to the contingencies made necessary by the uncertainty of the expected results, thus increasing production costs and impacting variability, productivity, and product quality (CHAN; AU, 2009; LEE et al., 2006; MAK; PICKEN, 2000).

However, very few studies have used a quantitative approach when investigating delay times in construction projects. Among those few examples are Al-Momani's (2000) study of public construction projects in Turkey and the study by Hsieh, Lu and Wu (2004), who performed a survey of 90 public developments in the city of Taipei (Taiwan) on contract scope changes and construction delays. More recently, González et al. (2014) conducted a study in Santiago, Chile, relating the qualitative and quantitative causes of delays and their respective impact on construction time.

Another important finding from our literature review was that the causes of delays occur during 
construction. This article seeks to identify the causes of delays for a real estate project that is still in the economic feasibility phase. By aiming this analysis at an earlier time in the project's lifecycle, this study fills a gap in the existing literature on construction delays.

\section{Characterisation of the research}

The methodology used in this study consisted of a literature review and a descriptive quantitative case study divided into the following phases:

(a) literature review - the authors sought to present the current state of knowledge on construction delays in both the international and national contexts using The Science Direct and Capes periodicals databases, identifying authors who have investigated construction delays. The emphasis was on authors who worked with variables that can be characterised during the feasibility study phase of the real estate project;

(b) systematisation of the independent variables that cause construction delays, based on the bibliographical references obtained in step (a). From the 56 most cited variables, we selected number of floors, apartments per floor, completed projects, outsourced construction, total constructed area, planned time, construction duration,

delivered projects, manager experience, the age of the construction company, funding available and use of planning. In addition to these 12 variables, we propose a further 6 (number of bathrooms/apt, number of bedrooms, time between beginning of funding and construction, number of apartments, number of towers and simultaneous construction projects), totalling 18 variables to be processed by factor analysis;

(c) data collection - 274 real estate projects from the past 11 years were identified at the City Planning Department (Secretaria Municipal de Urbanismo - SEURB) of the city of Belém and at developers working in the target region of the study;

(d) statistical modelling - an initial study was conducted based on the descriptive statistics of the construction project and various forms of statistical modelling, such as correlation and multiple linear regression, were performed to examine the impact of the selected variables on construction delays. Factor analysis presented the best results as an indicator of possible construction delays. Although factor analysis cannot be the only element to be used by decision-makers, it is a very useful tool to help them in their decision-making; and

(e) data analysis - at the end of this research project, the authors reached conclusions regarding the purpose of the study as well as about its relevance and possible contributions to a better understanding of construction delays.

\section{Results of the research application \\ Characteristics of the sample}

Between 24/08/2015 and 11/09/2015, we conducted a search and evaluation at the archives of the City Planning Department (SEURB) of the city of Belém, which is the governmental agency responsible for analysing and authorising construction projects to be executed in the city. The purpose of the search was to identify real estate developments with 4 to 37 floors; $93.1 \%$ of the construction projects in the archives were residential projects and $6.9 \%$ were commercial projects, all of them approved and authorized for execution. During the past 11 years, a total of 274 real estate projects were identified, totalling $5,329,084.36 \mathrm{~m}^{2}$ involving 101 companies, as described in Table 2.

The sample showed that $4.7 \%$ of the projects were abandoned or halted, $34.5 \%$ are still under construction, and $60.95 \%$ were completed. Hence, 167 projects were completed; however, several of these projects (25 real estate projects) did not present consistent information in the SEURB archives or were commercial or small $\left(<1.000 \mathrm{~m}^{2}\right)$ projects and were therefore excluded from the sample. For this reason, the research sample was limited to 142 projects.

\section{Delayed construction projects}

The completed projects were built by 28 developers who work in the state of Pará and in other parts of the country. This study involves buildings completed between 2005 and 2015, including projects with various standards of workmanship, sizes, building typologies and locations, denoted as P1 to P142.

Table 3 presents the completion performance of the construction projects in relation to the predicted completion time in the feasibility study. 
Table 2 - Number of real estate projects

\begin{tabular}{c|c|c|c|c|c|c}
\hline Year & $\begin{array}{c}\text { Projects w/ } \\
\text { permits }\end{array}$ & $\begin{array}{c}\text { Halted } \\
\text { projects }\end{array}$ & $\begin{array}{c}\text { Projects under } \\
\text { construction }\end{array}$ & $\begin{array}{c}\text { Completed } \\
\text { projects }\end{array}$ & $\begin{array}{c}\text { Number of } \\
\text { residential } \\
\text { projects }\end{array}$ & $\begin{array}{c}\text { Number of } \\
\text { commercial } \\
\text { projects }\end{array}$ \\
\hline 2005 & 20 & 1 & 0 & 17 & 20 & 0 \\
2006 & 33 & 1 & 0 & 25 & 29 & 4 \\
2007 & 35 & 3 & 1 & 26 & 30 & 5 \\
2008 & 35 & 1 & 1 & 31 & 34 & 1 \\
2009 & 29 & 2 & 6 & 16 & 26 & 3 \\
2010 & 32 & 1 & 11 & 19 & 31 & 1 \\
2011 & 25 & 1 & 16 & 7 & 24 & 1 \\
2012 & 20 & 1 & 17 & 1 & 20 & 0 \\
2013 & 18 & 0 & 18 & 0 & 18 & 0 \\
2014 & 22 & 2 & 19 & 0 & 21 & 1 \\
2015 & 5 & 0 & 5 & 0 & 5 & 0 \\
Total & 274 & 13 & 94 & 142 & 258 & 16 \\
\hline
\end{tabular}

Table 3 - Percentage of projects completed within the planned construction time

\begin{tabular}{c|c|c|c|c}
\hline $\begin{array}{c}\text { Planned } \\
\text { time } \\
\text { (month) }\end{array}$ & $\begin{array}{c}\text { Number of } \\
\text { projects }\end{array}$ & $\begin{array}{c}\text { Sample } \\
\text { percentage }\end{array}$ & $\begin{array}{c}\text { Number of delayed } \\
\text { projects }\end{array}$ & $\begin{array}{c}\text { Percentage of delayed } \\
\text { sample per planned time }\end{array}$ \\
\hline 18 & 2 & $1.40 \%$ & 1 & $50.00 \%$ \\
24 & 7 & $4.90 \%$ & 6 & $85.71 \%$ \\
32 & 16 & $11.19 \%$ & 14 & $87.50 \%$ \\
34 & 1 & $0.70 \%$ & 1 & $100.00 \%$ \\
36 & 61 & $42.66 \%$ & 55 & $90.16 \%$ \\
37 & 1 & $0.70 \%$ & 1 & $100.00 \%$ \\
40 & 3 & $2.10 \%$ & 18 & $33.33 \%$ \\
42 & 22 & $15.38 \%$ & 18 & $81.82 \%$ \\
48 & 26 & $18.18 \%$ & 1 & $69.23 \%$ \\
62 & 3 & $2.10 \%$ & & $33.33 \%$ \\
\hline
\end{tabular}

Table 3 shows that most real estate projects in the city were planned with a delivery time of 36 months (42.66\%, 61 developments), followed by developments with a lead time of 42 months $(15.38 \%)$ and 48 months (18.18\%). That is evidence of a market trend that promises construction completion at between 36 and 48 months (76.22\%).

The table also shows that, regardless of the planned construction time, there is a very high delay trend; 116 projects were delivered after the predicted deadline, which represents $81.69 \%$ of all the cases. This observation demonstrates that delays are a critical problem for developers and construction companies in the region.

The construction projects were then classified according to the built area: $1.7 \%$ were considered small (up to $1,500 \mathrm{~m}^{2}$ ); $14.7 \%$ were average (between $1,501 \mathrm{~m}^{2}$ and $7,500 \mathrm{~m}^{2}$ ); and $83.6 \%$ were large (larger than 7,500 $\mathrm{m}^{2}$ ).

Another aspect that the data revealed concerns the physical and geometrical characteristics of the buildings. The typologies of the buildings constructed in the past 11 years are highly diverse, however, the predominance of housing units consisting of 3 bedrooms with private bathrooms $(30.99 \%)$ or 1 bedroom with a private bathroom plus 2 bedrooms $(28.17 \%)$.

All the buildings in the sample have between 4 and 37 floors in total, and are distributed between 1 and 20 towers. The total area of the construction projects varies from approximately $1,000 \mathrm{~m}^{2}$ to $144,000 \mathrm{~m}^{2}$.

The buildings follow the traditional trend in building construction in the region, i.e., they are characterised by deep foundations, reinforcedconcrete structures cast in situ, and interior and exterior vertical sealing elements with ceramic blocks. The exterior walls and floors are made of concrete, and sand mortar is used as substrate for ceramic tiles. The interior floors are ceramic or porcelain tiles in all the rooms, and wall ceramic tiles are used in the kitchens and bathrooms. 


\section{Data processing}

The independent variables in this study, shown in Table 4, were identified and adapted from the literature review or created by the authors. Since these variables are specific to residential buildings, other variables would have to be identified for other construction types such as industrial buildings, commercial buildings or infrastructure projects.

As previously mentioned, these variables were selected in order to study their effects on construction delays during the economic feasibility phase, with the aim of providing better information to the decision makers conducting the business analysis. This selection consists of 12 variables from the literature and six variables proposed by the authors of this study (see methodology). The authors have not included the relationships between the construction company, developers and designers and the delivery method used, factors which are generally not yet known in the preliminary phase of a real estate project.

\section{Delay quantification}

This study investigates delays in the completion of construction projects. Delays were calculated as the difference between the actual time required to execute the construction phase of the project and the construction time specified in the project feasibility study. To determine the former, two official parameters from SEURB were used: the difference between the issue date of the occupancy permit and the issue date of the construction permit. The planned construction time (V7-Planned time) was obtained from the purchase and sale contract deadline between the developers and their clients. Figure 1 shows how delays were calculated in this study.

Table 4 - Independent variables

\begin{tabular}{|c|c|}
\hline Variables & Authors \\
\hline Number of bathrooms/apt* & \multirow{4}{*}{$\begin{array}{l}\text { Günhan and Arditi (2007), Han, Love and } \\
\text { Peña-Mora (2013) and Russell et al. (2014) }\end{array}$} \\
\hline Number of bedrooms/apt* & \\
\hline Number of floors & \\
\hline Apartments per floor & \\
\hline Completed projects & \multirow{3}{*}{$\begin{array}{l}\text { Alaghbari et al. (2007), Al-Momani (2000), } \\
\text { Filippi and Melhado (2015) and González et al. } \\
(2014)\end{array}$} \\
\hline Time between beginning of funding and construction* & \\
\hline Outsourced construction & \\
\hline Number of apts* & \multirow{3}{*}{$\begin{array}{l}\text { Assaf and Al-Hejji (2006) and Golanaraghi and } \\
\text { Alkass (2012) }\end{array}$} \\
\hline Total constructed area & \\
\hline Number of towers* & \\
\hline Planned time & \multirow{2}{*}{$\begin{array}{l}\text { Alsehaimi et al. (2013) and Hamzah et al. } \\
\text { (2011) }\end{array}$} \\
\hline Construction duration & \\
\hline Delivered projects & \multirow{3}{*}{$\begin{array}{l}\text { Alaghbari et al. (2007), Assaf and Al-Hejji } \\
\text { (2006), Ika (2015) and Alsehaimi et al. (2013) }\end{array}$} \\
\hline Simultaneous construction projects* & \\
\hline Manager experience & \\
\hline Time company exists & $\begin{array}{l}\text { Al-Momani (2000) and Gündüz, Nielsen and } \\
\text { Özdemir (2012) }\end{array}$ \\
\hline Funding available & \multirow{2}{*}{$\begin{array}{l}\text { Alaghbari et al. (2007), Alsehaimi et al. (2013) } \\
\text { and Assaf and Al-Hejji (2006) }\end{array}$} \\
\hline Use of planning & \\
\hline
\end{tabular}

Note: *variables not identified in the literature and proposed in this article.

Figure 1 - Representation of the calculation of construction delays

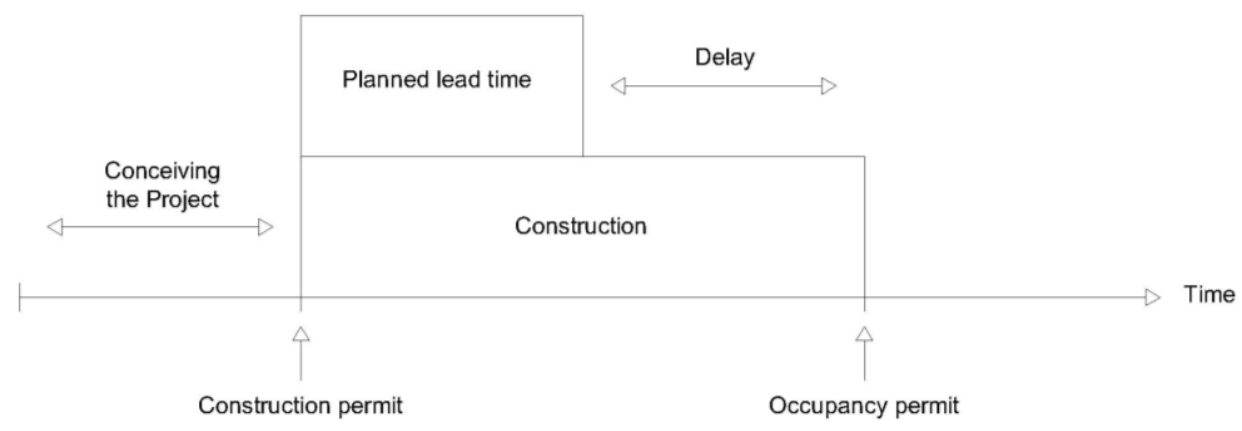


In the 116 real estate projects investigated in this study, the average delay was 23 months, with a variation amplitude of 44 months, ranging between 18 and 62 months.

\section{Factor analysis}

Factor analysis is a statistical technique based on the multivariate correlation of interdependence; factor analysis identifies when a sample presents a strong correlation in order to determine relations among variables (FÁVERO et al., 2009). The purpose of this technique is to reduce multiple variables to a smaller number of factors to define the process (BUZZI, 2010; ÖCAL et al., 2007; PALLANT, 2011). According to Hair et al. (2009), the size of the sample must be greater than 100 observations; nevertheless, it is preferable to use samples with five times more observations than the number of variables being analysed.

Based on the correlations observed between the original variables, the common factors derived from the original variables can be estimated. According to Johnson and Wichern (2007), this common factor occurs due to a high correlation between the derived variables and weak correlations with variables derived from another factor.

According to Fávero et al. (2009) and Pallant (2011), factor analysis can be classified as either confirmatory, which is when the researcher has some previous knowledge about the behaviour of the variables and the structure of the factors is already known, or exploratory, which is when the researcher has little knowledge about the structure of the factors. In this case, little or no previous investigation had been conducted to on several of the variables, such as the physical nature of construction delays. Hence, the factor analysis conducted in this study was exploratory.

\section{Results and discussions of the factor analysis}

The primary reason for using factor analysis was to identify which independent variables have greater impact on construction delays, as shown in Table 05 . In order to identify the main categories (factors) and to define which factors have a significant correlation with construction delays, the study used principal component analysis with varimax rotation with 25 interactions, eigenvalues $>1$ (the specific values for each factor), Kaiser criterion (PALLANT, 2011).

The first step was to analyse the correlation matrix for the 18 selected variables with normalised values. The results of the Kaiser-Meye-Olkin (KMO) test and Bartlett's test of sphericity (BTS) are presented in Table 5.

According to Fávero et al. (2009), the KMO test results vary between 0 and 1 , and a higher value indicates a better correlation for the factor sets identified in the factor analysis; therefore, KMO is used as the validation parameter of the analysis. The KMO result of 0.53 indicates a median correlation, thus validating the study. The BTS test is a hypothesis test in which factor analysis is accepted when its value approaches 0.000 , rejecting the hypothesis of the correlation matrix being the identity matrix.

Hence, the results, as presented in Table 6 , demonstrate the validity of the factor analysis.

The 18 variables and seven factors present commonality indices greater than 0.50 ; the eigenvalues of their components are greater than 1 , thus explaining $80.241 \%$ of the total variance. The analysis of the correlation matrix showed that the variables that had higher indices of correlation were: V1-Number of bathrooms/apt with V2Number of bedrooms/apt (0.859); V1-Number of bathrooms/apt with V6-Number of floors (0.601); V3-Total constructed area with V5-Number of apts (0.832); V4-Number of towers with V5-Number of apts (0.743); and V13-Time between beginning of funding and construction with variables V14Completed projects (0.873) and V16-Outsourced construction (0.706). The first four correlations were all related to physical aspects of the construction projects

The analysis of the matrix of rotational components was used to visualise the variables that compose the factors, as shown in Table 7 , since each of the variables presented only one significant factor loading in each of the factors, aiding in their interpretation and identification.

Table 5 - KMO and Bartlett tests

\begin{tabular}{l|r}
\hline Kaiser-Meyer-Olkin (KMO) measure of sampling adequacy & 0.530 \\
Bartlett's test of sphericity (BTS) - Significance & 0.000 \\
Chi-squared X2 & 1511.888 \\
Degree of freedom & 153 \\
\hline
\end{tabular}


Table 6 - Commonality indices and eigenvalues and eigenfactors

\begin{tabular}{|c|c|c|c|c|c|}
\hline Variables & $\begin{array}{c}\text { Commona- } \\
\text { lities }\end{array}$ & Factors & $\begin{array}{c}\text { Rotational } \\
\text { Eigenvalues }\end{array}$ & $\%$ Variance & $\%$ Accumulated \\
\hline $\begin{array}{l}\text { V1-Number of } \\
\text { bathrooms/apt }\end{array}$ & 0.874 & 1 & 2.859 & 15.882 & 15.882 \\
\hline $\begin{array}{l}\text { V2-Number of } \\
\text { bedrooms/apt }\end{array}$ & 0.777 & 2 & 2.660 & 14.778 & 30.660 \\
\hline $\begin{array}{c}\text { V3-Total } \\
\text { constructed area }\end{array}$ & 0.834 & 3 & 2.652 & 14.736 & 45.395 \\
\hline $\begin{array}{c}\text { V4-Number of } \\
\text { towers }\end{array}$ & 0.696 & 4 & 1.891 & 10.504 & 55.900 \\
\hline $\begin{array}{l}\text { V5-Number of } \\
\text { apts }\end{array}$ & 0.934 & 5 & 1.775 & 9.860 & 65.760 \\
\hline $\begin{array}{l}\text { V6-Number of } \\
\text { floors }\end{array}$ & 0.736 & 6 & 1.386 & 7.700 & 73.460 \\
\hline V7-Planned time & 0.983 & 7 & 1.220 & 6.780 & 80.241 \\
\hline $\begin{array}{c}\text { V8-Time } \\
\text { company exists }\end{array}$ & 0.890 & & & & \\
\hline $\begin{array}{l}\text { V9- Delivered } \\
\text { projects } \\
\text { V10- }\end{array}$ & 0.790 & & & & \\
\hline $\begin{array}{l}\text { Simultaneous } \\
\text { construction } \\
\text { projects }\end{array}$ & 0.659 & & & & \\
\hline $\begin{array}{l}\text { V11-Manager } \\
\text { experience }\end{array}$ & 0.736 & & & & \\
\hline $\begin{array}{l}\text { V12-Funding } \\
\text { available }\end{array}$ & 0.814 & & & & \\
\hline $\begin{array}{l}\text { V13-Time } \\
\text { between }\end{array}$ & & & & & \\
\hline $\begin{array}{l}\text { beginning of } \\
\text { funding and } \\
\text { construction }\end{array}$ & 0.904 & & & & \\
\hline $\begin{array}{l}\text { V14- Completed } \\
\text { projects }\end{array}$ & 0.906 & & & & \\
\hline $\begin{array}{l}\text { V15-Use of } \\
\text { planning }\end{array}$ & 0.666 & & & & \\
\hline $\begin{array}{l}\text { V16-Outsourced } \\
\text { construction }\end{array}$ & 0.777 & & & & \\
\hline $\begin{array}{l}\text { V17-Apartments } \\
\text { per floor } \\
\text { V18- }\end{array}$ & 0.526 & & & & \\
\hline $\begin{array}{l}\text { Construction } \\
\text { duration }\end{array}$ & 0.940 & & & & \\
\hline
\end{tabular}


Table 7 - Rotational component matrix

\begin{tabular}{|c|c|c|c|c|c|c|c|}
\hline \multirow{2}{*}{ Variables } & \multicolumn{7}{|c|}{ Variables with factor loading $>0.5$} \\
\hline & F1 & $\mathrm{F} 2$ & F3 & $\mathrm{F} 4$ & F5 & F6 & F7 \\
\hline V1-NumberBathroomsApt & .903 & & & & & & \\
\hline V2-NumberBedroomsApt & .841 & & & & & & \\
\hline V6-NumberoofFloors & .749 & & & & & & \\
\hline V17-ApartamentsPerFloor & -.537 & & & & & & \\
\hline V14-CompletedConstruc & & .918 & & & & & \\
\hline V13-TimeCompletedConstruc & & .898 & & & & & \\
\hline V16-OutsourcedConstruc & & .751 & & & & & \\
\hline V5-NumberApt & & & .947 & & & & \\
\hline V3-TotalConstrArea & & & .886 & & & & \\
\hline V4-NumberTowers & & & .756 & & & & \\
\hline V7-PlannedTime & & & & .937 & & & \\
\hline V18-ConstrucDuration & & & & .913 & & & \\
\hline V9-DeliveredConstruc & & & & & .857 & & \\
\hline V10-SimultaneousConstruc & & & & & 688 & & \\
\hline V11-ManagerExperience & & & & & .594 & & \\
\hline V8-TimeCompanyExists & & & & & & .912 & \\
\hline V12-FundingAvailable & & & & & & & .875 \\
\hline V15-UsedPlanning & & & & & & & .506 \\
\hline
\end{tabular}

Note: subsequently, the identified factors were interpreted as follows: Factor 1 - physical characteristics of the apartments; Factor 2 - management decisions; Factor 3 - size of the construction project; Factor 4 - execution time of the construction project; Factor 5 - construction expertise of the company; Factor 6 - operation time of the company, and Factor 7 - start-up conditions.

\section{Factor 1: physical characteristics of the apartments}

This factor was responsible for $15.882 \%$ of the total variance (see table 06) and consists of 4 significant variables: number of bathrooms per apartment (factor loading of 0.903), number of bedrooms per apartment (factor loading of 0.841), number of floors (factor loading of 0.749), and number of apartments per floor (factor loading of -0.537).

The literature does not objectively show that these variables are responsible for the occurrence of delays in construction projects. However, this study shows that these variables were highly important and are the most important factors in the sample. However, in dealing with delay, project planners include floats in their execution plans. In this process, the complexity of the project and the construction process are the most frequent causes for floats, which increase the execution time of the construction project (GÜNHAN; ARDITI, 2007; RUSSELL et al., 2014). Constructions with a large number of bedrooms and bathrooms are more complex to build, and taller buildings require more a careful study of vertical transport logistics. In addition, Han, Love and Peña-Mora (2013) stated that mistakes in complex projects create rework, which is one of the primary causes of construction delays.

\section{Factor 2: management decisions}

The second factor, namely management decisions, explains $14.778 \%$ of the total variance and is composed of three variables: completed projects (factor loading of 0.918), time interval between the release of funds and the beginning of the construction project (factor loading of 0.898), and outsourcing the construction project $(0.751)$.

Some authors point out that design issues, such as alterations and conflicts between designs and specifications (AL-MOMANI, 2000; GONZÁLEZ et al., 2014) contribute to problems that result in delays.

The decision to begin construction before the funds are available (MEZHER; TAWIL, 1998) causes interruptions in the work pace due to shortage of materials and equipment and leads to low motivation among workers. In addition, inadequate cash flow causes the company to make investments using their own funds, which can, sometimes, lead to insolvency (NTULI; ALLOPI, 2013).

Assaf and Al-Hejji (2006) stated that the type of contract for executing a construction project (key in 
the buyer's hands or construction only) is one of the ten most significant causes of construction delays in Saudi Arabia. Problems with outsourcing or with subcontractors also are frequent causes of construction delays in Brazil (FILIPPI; MELHADO, 2015) and in several other countries (HAMZAH et al., 2011).

\section{Factor 3: size of the construction project}

Factor 3 addresses the size of the development, which has a total variance of $14.736 \%$ in the sample and is composed of 3 variables: the number of apartments (factor loading of 0.947), the total constructed area (factor loading of 0.688 ) and the number of towers (factor loading of 0.756).

There are few studies in the literature that investigate the size of a construction project as a cause for delay. According to Assaf (2006), there are several causes for delays, including contractor performance, advanced planning, and conception of the project. Regarding the latter, larger projects are generally more complex, which may lead to more problems in their execution (GOLANARAGHI; ALKASS, 2012).

According to Russel et al. (2014), uncertainties during project implementation may result in difficulties completing the construction by the estimated deadline.

\section{Factor 4: execution time of the construction project}

The fourth factor presents an explanatory variance of $10.504 \%$ of the total and is composed of 2 variables related to the execution time of the construction project: the planned lead time (factor loading of 0.937) and the duration of the construction project (factor loading of 0.913).

It is essential to develop a detailed plan in order for the construction project to achieve a higher quality and to provide consistent information when determining the time required for construction. Several authors have mentioned this need when stating the necessity to improve planning and control because the actual time it takes to complete a project frequently exceeds the time planned (ALSEHAIMI et al., 2013; GONZÁLEZ et al., 2014; HAMZAH et al., 2011; HSIEH; LU; WU, 2004; KIM, 2009).

According to Assaf (2006), one of the causes of construction delays is that the predicted construction time is too short. Other authors have also noted that mistakes in the planning stage can lead to significant delays in construction time
(FILIPPI; MELHADO, 2015; MARZOUK; ELRASAS, 2014).

\section{Factor 5: construction expertise of the company}

This factor presents an explanatory variance of $9.860 \%$ of the total and is composed of 3 variables related to experience and ability to perform the construction project: number of completed construction projects (factor loading of 0.857), simultaneous construction projects (factor loading of 0.688), and experience of the construction manager (factor loading of 0.594).

The literature states that a manager who lacks experience is one of the most relevant causes of construction delays, resulting in poor management, slow decision making, and less successful projects (ASSAF; AL-HEJJI, 2006; IKA, 2015; MEZHER; TAWIL, 1998).

The time required to execute a specific task depends on many factors, and is variable by nature. Thus, this time can become another factor responsible for construction delays (GOLOB; BASTIČ; PŠUNDER, 2014; SHI; CHEUNG; ARDITI, 2001); these delays can be reduced as a result of the experience acquired while executing and controlling construction projects. According to Russell et al. (2014), process variation regarding time originates from lack of team work, lack of clarification from the engineer, completion of the previous task, obtaining a permit to begin construction, lack of good quality information, rework, etc. All of those aspects can be minimized with knowledge acquired by the company and by appropriately supervising the project, which is key, since these aspects significantly influence the expected project results (CHAUVET; COLLIER; FUSTER, 2006; IKA, 2015).

\section{Factor 6: operation time}

Operation time presents an explanatory variance of $7.700 \%$ of the total and is the length of time for which the company has been building residential projects (factor loading of 0.912), which represents the years the company has been in business; this factor is represented by only 1 variable.

Several authors have noted that lack of experience by the company results in lack of the necessary knowledge to execute the project, which is a cause of construction delays (AL-MOMANI, 2000; ALWI; HAMPSON, 2003; GÜNDÜZ; NIELSEN; ÖZDEMIR, 2012; HAMZAH et al., 2011; NTULI; ALLOPI, 2013; OTHUMAN MYDIN et al., 2014a). Thus, the size and experience of the 
company may be a success factor (LU; SHEN; YAM, 2008).

\section{Factor 7: start-up conditions}

Finally, the seventh factor presents an explanatory variance of $6.780 \%$ of the total and is composed of 2 variables: funding (factor loading of 0.875), which evaluates whether the company executes the construction project with their own funds or with funds from financial institutions, and the use of planning (factor loading of 0.506), which evaluates whether a plan and control technique was used for the construction project. The analysis shows that this is the least important variable, which is verified by the literature, and the variables that compose it occur more frequently during the execution of the construction project.

Several authors have described problems with payments and cash flow as causes of construction delays (ALSEHAIMI et al., 2013; MARZOUK; EL-RASAS, 2014; MEZHER; TAWIL, 1998). Assaf and Al-Hejji (2006) stated that one of the most important causes of construction delays is payment delays by the contracting party, which may be the developer or the financial agent; another problem is matching cash flow with the needs of the construction project.

An additional item cited in the literature is the lack of qualified managers with experience in supporting activities, such as construction planning and control (AL-MOMANI, 2000; ALSEHAIMI et al., 2013; GUDIENE et al., 2014; LI et al., 2013; MEZHER; TAWIL, 1998).

\section{Conclusions and future work}

Construction delays are a frequent and significant problem, particularly in developing countries, which explains the significant number of studies conducted on this topic by authors from those regions (DOLOI et al., 2012; FILIPPI; MELHADO, 2015; GONZÁLEZ et al., 2014; MARZOUK; EL-RASAS, 2014).

The goal of this research study was to use factor analysis to identify aspects of construction delays that have been less explored in the literature and to correlate some factors that may impact construction delays. This study used 18 variables, which are identified in Table 4; however, other factors are also likely to contribute to delays in construction projects.

This study focused on 18 variables that can be evaluated before construction begins and which can affect completion time. Factor analysis was used to classify the 18 variables into the following 7 groups, which were used to explain the relationships between the correlated variances:

(a) (F1) physical characteristics of the apartments;

(b) (F2) management decisions;

(c) (F3) size of the construction project;

(d) (F4) execution time of the construction project;

(e) (F5) construction expertise of the company;

(f) (F6) operation time; and

(g) (F7) start-up conditions.

The statistical results suggest that the physical characteristics of the housing units (F1) and the size of the construction project (F3) strongly influence construction delays. These factors have not yet been identified in the national or international literature as causes of construction delays, hence this represents a new contribution from this study. In addition, management decisions (F2) and execution time of the construction (F4) also impact the duration of the construction project (ALMOMANI, 2000; GONZÁLEZ et al., 2014).

On the other hand, the construction expertise of the company (F5), its operating time (F6), and the startup conditions (F7) have shown to have less influence on construction delays, which confirms the findings of previous studies (ALWI; HAMPSON, 2003; ASSAF; AL-HEJJI, 2006; DOLOI et al., 2012; MARZOUK; EL-RASAS, 2014; MEZHER; TAWIL, 1998).

After performing a factor analysis, this study showed that, for the region investigated, the physical characteristics of the apartments (F1), management decisions (F2), the size of the construction project (F3) and the execution time of the construction project $(\mathrm{F} 4)$ are responsible for a total variance of $55.90 \%$. From those factors, the physical characteristics of the apartments (F1) and the size of the construction project (F3) represent $30.617 \%$ of the variance, but they were not previously identified in the literature as factors responsible for construction delays, particularly in terms of the variables that compose these two factors (shown in Table 5).

Despite this gap, our findings suggest that greater attention should be paid to these characteristics in projects when determining construction completion time. In addition, it is essential to study these factors in more detail in order to verify how far they contribute to construction delays.

This study identifies decision-making aspects that have direct influence on whether a construction project is completed on schedule. These factors, related to geometrical aspects and size, should be 
highlighted, and they demonstrate the need for private developers to evaluate these issues more carefully.

Regarding the execution time of real estate projects, the use of conventional programming techniques such as PERT/CPM are recommended despite being laborious (SHI, 1999; SKITMORE; NG, 2003). This aspect still needs to be investigated more deeply, particularly with regards to the procedure for estimating the time required to execute a construction project. Refining this process could reduce delays related to these characteristics not only in real estate projects, but also in other types of project.

The conclusions of this study cannot yet be validated in other regions of Brazil or in other countries due to the peculiarities of each area. However, the methodological approach used in this research study can contribute to a better understanding of this topic, and provides an important tool for avoiding delay-related problems for real estate projects in the Brazilian Amazon region.

\section{References}

AKOGBE, R. K. T. M.; FENG, X.; ZHOU, J. Importance and Ranking Evaluation of Delay Factors for Development Construction Projects in Benin. KSCE Journal of Civil Engineering, v. 17, n. 6, p. 1213-1222, 2013.

ALAGHBARI, W. et al. The Significant Factors Causing Delay of Building Construction Projects in Malaysia. Engineering, Construction and Architectural Management, v. 14, n. 2, p. 192206, 2007.

AL-MOMANI, A. H. Construction Delay: a quantitative analysis. International Journal of Project Management, v. 18, n. 1, p. 51-59, 2000.

ALSEHAIMI, A. et al. Need for Alternative Research Approaches in Construction Management : case of delay studies. Journal of Management in Engineering, v. 29, oct., p. 407414, 2013.

ALWI, S.; HAMPSON, K. Identifying the Important Causes of Delays in Building Construction projectsthe 9th East Asia-Pacific Conference on Structural Engineering and Construction. Bali, 2003.

ASSAF, S. A.; AL-HEJJI, S. Causes of Delay in Large Construction Projects. International Journal of Project Management, v. 24, n. 4, p. 349-357, 2006.
BM\&FBOVESPA. Bovespa. Disponível em: <http://www.bmfbovespa.com.br/pt_br/>. Acesso em: 16 jul. 2015.

BUZZI, D. C. Diretrizes Para o Gerenciamento de Riscos em Incorporadoras da Construção Civil Uma Abordagem Utilizando Lógica Difusa. Florianópolis: UFSC, 2010.

CHAN, D. W.; KUMARASWAMY, M. M. A Comparative Study of Causes of Time Overruns in Hong Kong Construction Projects. International Journal of Project Management, v. 15, n. 1, p. 55-63, 1997.

CHAN, E. H.; AU, M. C. Factors Influencing Building Contractors' Pricing for Time-Related Risks in Tenders. Journal of Construction Engineering and Management, v. 135, n. 3, p. 135-145, 2009.

CHAPMAN, R. J. The Controlling Influences on Effective Risk Identification and Assessment for Construction Design Management. International Journal of Project Management, v. 19, n. 3, p. 147-160, 2001.

CHAUVET, L.; COLLIER, P.; FUSTER, A. Supervision and Project Performance: a principalagent approach. In: ECONOMICS Repository. University of Southampton, 2006.

COUTINHO, L. S. D. A. L. et al. Modelagem do Tempo de Execução de Obras Civis: estudo de caso na Universidade Federal do Pará. Ambiente Construído, Porto Alegre, v. 12, n. 1, p. 243-256, jan./mar. 2012.

DAI, J.; GOODRUM, P. M.; MALONEY, W. F. Construction Craft Workers' Perceptions of the Factors Affecting Their Productivity. Journal of Construction Engineering and Management, v. 135, n. 3, p. 217-226, 2009.

DOLOI, H. et al. Analysing Factors Affecting Delays in Indian Construction Projects. International Journal of Project Management, v. 30, n. 4, p. 479-489, 2012.

FÁVERO, L. P. et al. Análise de Dados: modelagem multivariadas para tomada de decisões. 8. ed. São Paulo: Campus, 2009.

FILIPPI, G. A. de; MELHADO, S. B. Um Estudo Sobre as Causas de Atrasos de Obras de Empreendimentos Imobiliários na Região Metropolitana de São Paulo. Ambiente Construído, Porto Alegre, v. 15, n. 3, p. 161-173, jul./set. 2015. 
FUGAR, F. D. K.; AGYAKWAH-BAAH, A. B. Delays in Building Construction Projects in.

Australasian Journal of Construction Economics and Building, v. 10, n. 1/2, p. 103116, 2010.

FUNDAÇÃO JOÃO PINHEIRO. CENTRO DE ESTATÍSTICA E INFORMAÇÃO. Nota Técnica 1 Déficit Habitacional no Brasil 2011-2012

Resultados Preliminares. Belo Horizonte, 2014. Disponível em:

<http://www.fjp.mg.gov.br/index.php/docman/cei/ deficit-habitacional/363-deficit-nota-tecnica-dh2012/file>. Acesso em: 23 jul. 2015

GOLANARAGHI, S.; ALKASS, S. Modified Isolated Delay Type Technique. Construction Research Congress 2012 (C) ASCE 2012 Type, n. Chinowsky 2011, p. 2001-2010, 2012.

GOLOB, K.; BASTIČ, M.; PŠUNDER, I. Factors Influencing Construction Labor Productivity in Egypt. Journal of Management in Engineering, v. 29, p. 1-9, fev. 2014.

GONZÁLEZ, P. et al. Analysis of Causes of Delay and Time Performance in Construction Projects. Journal of Construction Engineering and Management, v. 140, n. 1, p. 1-9, 2014.

GUDIENE, N. et al. Identification and Evaluation of the Critical Sucess Factors for Construction Projects in Lithuania: AHP approach.pdf. Journal of Civil Engineering and Management, v. 20, n. 3, p. 350-359, 2014.

GÜNDÜZ, M.; NIELSEN, Y.; ÖZDEMIR, M. Quantification of Delay Factors Using the Relative Importance Index Method for Construction Projects in Turkey. Journal of Management in Engineering, v. 29, p. 133-139, apr. 2012.

GÜNDÜZ, M.; NIELSEN, Y.; ÖZDEMIR, M. Fuzzy Assessment Model to Estimate the Probability of Delay in Turkish Construction Projects. Journal of Management in Engineering, v. 31, n. 4, p. 1-14, 2013.

GÜNHAN, S.; ARDITI, D. Budgeting Owner's Construction Contingency. Journal of Construction Engineering and Management, p. 492-497, jul. 2007.

HAIR, J. F. et al. Análise Multivariadas de Dados. 6. ed. Porto Alegre, Bookman, 2009.

HAMZAH, N. et al. Cause of Construction Delay: theoretical framework. Procedia Engineering, v. 20, p. 490-495, 2011.
HAN, S.; LOVE, P.; PEÑA-MORA, F. A System Dynamics Model for Assessing the Impacts of Design Errors in Construction Projects.

Mathematical and Computer Modelling, v. 57, n. 9/10, p. 2044-2053, 2013.

HSIEH, T.; LU, S.; WU, C. Statistical Analysis of Causes for Change Orders in Metropolitan Public Works. International Journal of Project Management, v. 22, n. 8, p. 679-686, 2004.

IKA, L. A. Opening the Black Box of Project Management: Does World Bank project supervision influence project impact? International Journal of Project Management, v. 33, n. 5, p. 1111-1123, 2015.

INSTITUTO BRASILEIRO DE GEOGRAFIA E ESTATÍSTICA. Pesquisa Anual da Indústria da Construção. Rio de Janeiro: Ministério do Planejamento, Orçamento e Gestão, 2012.

INSTITUTO BRASILEIRO DE GEOGRAFIA E ESTATÍSTICA. PIB Nacional. Disponível em: <www.ibge.gov.br/home/.../000000077652031120 12522606619383.xls>. Acesso em: 20 jul. 2015.

JOHNSON, R. A.; WICHERN, D. W. Applied Multivariate Statistical Analysis. 6. ed. Upper Saddle River, Pearson Education, 2007.

KAZAZ, A.; ULUBEYLI, S.; TUNCBILEKLI, N. A. Causes of Delays in Construction Projects in Turkey. Journal of Civil Engineering and Management, v. 18, n. 3, p. 426-435, 2012.

KIM, K. Delay Analysis in Resource-Constrained Schedules. Canadian Journal of Civil Engineering, v. 36, p. 295-303, 2009.

LEE, H. et al. Considering Lost Productivity. Journal of Construction Engineering and Management, v. 131, n. 11, p. 1147-1154, 2006.

LEE, J.-S.; DIEKMANN, J. E. Delay Analysis Considering Production Rate. Canadian Journal of Civil Engineering, v. 38, p. 361-372, 2011.

LI, H. X. et al. Risk Identification and Assessment of Modular Construction Utilizing Fuzzy Analytic Hierarchy Process (AHP) and Simulation.

Canadian Journal of Civil Engineering, v. 40, n. 12, p. 1184-1195, 2013.

LU, W.; SHEN, L.; YAM, M. Critical Success Factors for Competitiveness of Contractors: a China study. Journal of Construction Engineering and Management, v. 134, p. 972982, dec. 2008.

MAK, S.; PICKEN, D. Using Risk Analysis to Determine Construction Project Contingencies. Journal of Construction Engineering and Management, v. 126, p. 130-136, apr. 2000. 
MARZOUK, M. M.; EL-RASAS, T. I. Analyzing Delay Causes in Egyptian Construction Projects. Journal of Advanced Research, v. 5, n. 1, p. 49$55,2014$.

MEZHER, T. M.; TAWIL, W. Causes of Delays in the Construction Industry in Lebanon.

Engineering, Construction and Architectural Management, v. 5, n. 3, p. 252-260, 1998.

NTULI, B.; ALLOPI, D. Impact of Inadequate Experience and Skill on the Construction Sector in KwaZulu-Natal, South Africa. Engineering,

Technology \& Applied Science Research, v. 3, n. 9, p. 30-38, 2013.

ÖCAL, M. E. et al. Industry Financial Ratios: Application of Factor Analysis in Turkish Construction Industry. Building and

Environment, v. 42, p. 385-392, 2007.

OTHUMAN MYDIN, M. A. et al. Assessment of Influential Causes of Construction Project Delay in Malaysian Private Housing from Developer's Viewpoint. E3S Web of Conferences, v. 3, p. 01027, 2014a.

PALLANT, J. SPSS Survival Manual: a step by step guide to data analysis using SPSS. $4^{\text {th }}$ ed. Crows Nest: Allen and Unwin, 2011.

PROJECT MANAGEMENT INSTITUTE. Um Guia do Conhecimento em Gerenciamento de Projetos (Guia PMBOK). Pennsylvania, 2013.

RUSSELL, M. M. et al. Causes of Time Buffer and Duration Variation in Construction Project Tasks : Comparison of Perception to Reality. Journal of Construction Engineering and Management, v. 140, n. 6, p. 12, 2014.

SHI, J. J. Activity-Based Construction (ABC) Modeling and Simulation Method. Journal of Construction Engineering and Management, v. 125, n. 5, p. 354-360, oct. 1999.

SHI, J. J.; CHEUNG, S. O.; ARDITI, D.

Construction Delay Computation Method. Journal of Construction Engineering and Management, v. 127, n. 1, p. 60-65, 2001.
SKITMORE, R. M.; NG, S. T. Forecast Models for Actual coNstruction Time and Cost. Building and Environment, v. 38, n. 8, p. 1075-1083, 2003.

SOUZA, F. F. DE A. Análise das Influências das estratégIas de Diversificação e dos Modelos de Negócios no Desempenho das Empresas de Real Estate no Período 2005 A 2010. São Paulo, 2011. Dissertação (Mestrado em Engenharia Civil) Programa de Pós-Graduação em Engenharia Civil, Universidade de São Paulo, São Paulo, 2011.

SWEIS, G. et al. Delays in Construction Projects: the case of Jordan. International Journal of Project Management, v. 26, n. 6, p. 665-674, 2008.

UHER, T. E.; TOAKLEY, A. R. Risk

Management in the Conceptual Phase of a Project. International Journal of Project Management, v. 17, n. 3, p. 161-169, 1999.

WAMBEKE, B. W.; HSIANG, S. M.; LIU, M. Causes of Variation in Construction Project Task Starting Times and Duration. Journal of Construction Engineering and Management, v. 137, p. 663-677, sep. 2011.

WIDEMAN, R. M. Successful Project Control and Execution. International Journal of Project Management, v. 7, n. 2, p. 109-113, 1989.

YANG, J.-B.; WEI, P.-R. Causes of Delay in the Planning and Design Phases for Construction Projects. Journal of Architectural Engineering, v. 16, n. 2, p. 80-83, 2010.

ZAVADSKAS, E. K.; TURSKIS, Z.;

TAMOSAITIENE, J. Risk Assessment of Construction Projects.pdf. Journal of Civil Engineering and Management, v. 18, n. 1, p. 33 46, 2010.

ZOU, P. X. W.; ZHANG, G.; WANG, J. Understanding the Key Risks in Construction Projects in China. International Journal of Project Management, v. 25, n. 6, p. 601-614, 2007. 


\section{Luiz Mauricio Furtado Maués}

Faculdade de Engenharia Civil | Universidade Federal do Pará | Av. Augusto Corrêa, s/n, Guamá | Belém - PA - Brasil | CEP $66075-110$ Tel.: (91) 3201-7917 | E-mail: maues@ufpa.br

\section{Wylliam Bessa Santana}

Programa de Pós-Graduação em Engenharia Civil | Universidade Federal do Pará | E-mail: wyll_santana@hotmail.com

\section{Paulo Cerqueira dos Santos}

Faculdade de Estatística | Universidade Federal do Pará | Tel.: (91) 3201-8950 | E-mail: cerquera@ufpa.br

\section{Renato Martins das Neves}

Departamento de Engenharia Civil, Centro Tecnológico | Universidade Federal do Pará | Tel.: (91) 3201-7917 | E-mail: neves@ufpa.br

\section{André Augusto Azevedo Montenegro Duarte}

Faculdade de Engenharia Civil, Instituto de Tecnologia | Universidade Federal do Pará | Tel.: (91) 3201-8200 Ramal 8200 |

E-mail: amonte@ufpa.br

Revista Ambiente Construído

Associação Nacional de Tecnologia do Ambiente Construído

Av. Osvaldo Aranha, $99-3^{\circ}$ andar, Centro

Porto Alegre - RS - Brasil

CEP 90035-190

Telefone: +55 (51) 3308-4084

Fax: +55 (51) 3308-4054

www.seer.ufrgs.br/ambienteconstruido

E-mail: ambienteconstruido@ufrgs.br 